\title{
Integration of Negativity, Powerlessness and the Role of the Mediopassive: Resilience Factors and Mechanisms in the Perspective of Religion and Spirituality
}

\author{
Cornelia Richter \\ Professor of Systematic Theology, Evangelisch-Theologische Fakultät, \\ Rheinische Friedrich-Wilhelms-Universität Bonn, Bonn, Germany \\ cornelia.richter@uni-bonn.de
}

\begin{abstract}
Defining psychological resilience while taking into account all of its different facets has proven to be a difficult task, requiring an interdisciplinary and transdisciplinary approach. This article will present some of the theologically relevant current findings of the new research group on "Resilience in Religion and Spirituality" (DFG-FOR 2686) working in cooperation between theology, philosophy, psychosomatic medicine, palliative care, and spiritual care (chapter 1). Even though our project builds on factors and mechanisms of resilience already intensively discussed (chapter 2), we will add some further aspects on resilience as a multidimensional and dynamic process of adaption (chapter 3 ) and on the integration of negative experiences, of endurance, of the formation of powerlessness and of the mediopassive (chapter 4). This will allow for some prospective considerations on understanding challenges and problems of the current SARS-CoV-2 pandemic (chapter 5$)$.
\end{abstract}

\section{Keywords}

resilience factors - resilience mechanisms - powerlessness - negativity - mediopassive 
Defining psychological resilience while taking into account all of its different facets has proven to be an increasingly difficult task, requiring inter- and transdisciplinary mixed-methods approach and including manifold theoretical perspectives. Hence, starting a new research group on resilience, as a highly complex phenomenon, demands significant reading of the literature on psychology, sociology and philosophy, while touching on various aspects of individuals as well as collective social, cultural, economic and political dimensions. ${ }^{2}$ It is due to the impressive research already performed that our research group Resilience in Religion and Spirituality is able to build upon the results and add some new perspectives from our own specific fields of expertise.

The members of our research group come from various sub-disciplines of theology, philosophy, psychosomatic medicine and psychotherapy, palliative care, pastoral and spiritual care. We started to collaborate in 2014 and have received substantial funding as a DFG-research group since 2019. In fact, our programme title for 2019-2022 is Endurance and the Formation of Powerlessness, Fear and Anxiety. ${ }^{3}$ In our fields relevant to diagnostics, therapy and pastoral and spiritual care, we are approached by individuals who experience difficult situations for manifold reasons: mental or physical issues including fear, anxiety, stress, trauma, severe illness and/or terminal states; experiences of loss of control, flexibility, agility, autonomy or the loss of a loved one; and experiences of grief and solitude, helplessness, powerlessness, exclusion, etc. In these contexts, the concept of individual resilience or the resilience of an individual (both terminologies are state of the art) is of high value, since it helps us determine, whether and if so, why and how patients/clients are able to cope quite well with difficult situations. Additionally, it helps us decide the level and type of therapeutic or accompanying intervention might be required.

Stressing individual resilience, however, does not mean ignoring the simple fact that all of our patients/clients are bound to their social surroundings, i.e.

1 Funded by Deutsche Forschungsgemeinschaft (DFG) - Project No. 348851031.

2 Cf. e.g. Karidi/Schneider/Gutwald (eds.), Resilienz; Blum, Endreß/Kaufmann/Rampp, Soziologische Perspektiven.

3 DFG-Research Group 2686 Resilience in Religion and Spirituality. Endurance and the Formation of Powerlessness, Fear and Anxiety, 2019-2022: Cornelia Richter (Chairperson; Protestant Theology/Systematic Theology); Thiemo Breyer (Philosophy/Phenomenology and Anthropology); Judith Gärtner (Protestant Theology/Old Testament); Franziska Geiser (Psychosomatic Medicine and Psychotherapy); Eberhard Hauschildt (Protestant Theology/ Spiritual Care); Constantin Klein (Protestant Theology/Spiritual Care); Simon Peng-Keller (Catholic Theology/Spiritual Care); Lukas Radbruch (Palliative Medicine); and Jochen Sautermeister (Catholic Theology/Ethics and Moral Theology). 
family, friends, relevant institutions, societal structures and values, so that individual resilience is inevitably connected to collective resilience. Thus, as resilience develops in both individual and social contexts, we investigate interpersonal relations, solidarity, empathy and mindfulness, with the help of phenomenology, anthropology and moral theology and seek various forms of cooperation with our colleagues from the social sciences. ${ }^{4}$ Within the social and interpersonal domain, resilience finds expression in diverse semantic and symbolic reactions to actual and expected scenarios. Accordingly, we imply a thorough hermeneutic approach, including the methods of exegetical, philological and literature studies.

The early weeks of the ongoing SARS-CoV-2 pandemic, responsible for the disease called Covid-19, for example, have generated intense, dramatic expressions of catastrophic, even apocalyptic scenarios as well as semantics of neglecting/denying a crisis by displaying individual strength, salvation or redemption. Hence, in the hermeneutic approach of our group, we combine historical perspectives, cultural theory, systematic theology and anthropology to investigate the impact of religious and spiritual semantics and symbols on resilience in the intercultural dimension of this pandemic.

Overall, this study presents the aim of our research group and some new aspects developed in cooperation between theology, philosophy, psychosomatic medicine, palliative care and spiritual care. Even though our project builds on the factors, mechanisms and outcomes of resilience previously researched (Chapter 2), we add some hermeneutic reflections on such aspects, as a multi-dimensional and dynamic process of adaption (Chapter 3), and on the integration of negativity, powerlessness and the role of the mediopassive (Chapter 4). This will allow for some prospective considerations on understanding the challenges and problems of the current SARS-CoV-2 pandemic (Chapter 5).

\section{Common Understandings of Resilience and Their Critique}

\subsection{Waves of Resilience Research}

Research on resilience builds on the idea that human beings (to a surprisingly high extent) are able to cope with stress and adversity in individual and social respects. In 2013, Wu et al. introduced a helpful definition of resilience: "Resilience is the capacity and dynamic process of adaptively overcoming

4 For a complementing sociological perspective on resilience, cf. Endreß/Maurer (eds.), Resilienz im Sozialen. 
stress and adversity while maintaining normal psychological and physical functioning". ${ }^{5}$ As researchers in the field of neuroscience, Wu et al.'s definition was clearly directed towards individual resilience in situations of "stressful live events, trauma and chronic adversity", potentially leading to "posttraumatic stress disorder (PTSD), depression and other psychiatric disorders". 6 Their definition is significant as it mirrors the state of the art in 2013 and allows for a careful balance between resilience as a capacity, a dynamic process and an outcome-related process, without stressing one part of the definition over another.

This matches and is simultaneously topped by Fletcher and Sarkar who, similar to Windle, ${ }^{7}$ discussed why the question of defining resilience proves to be so complex. In their extremely rich and comprehensive article Psychological Resilience: A Review and Critique of Definitions, Concepts and Theory, Fletcher and Sarkar identified the rapidly growing variety of definitions, concepts and theories of resilience, as core problems of resilience research. ${ }^{8}$ In all three respects, they not only hinted at the increasing awareness of the different approaches concerning traits, process or outcomes, but they also displayed the manifold terminological variations of factors and mechanisms of resilience, including protective and risk factors, and external preconditions and circumstances such as economic, social or educational issues. ${ }^{9}$ This has made it even more difficult to find an overall definition of resilience. Specifically, the definitions have varied according to the objective of the research and the respective target groups and contexts, including: children in childcare or schools; patients, clients or staff in clinical and therapeutic contexts or in hospices; soldiers, veterans or mourners in pastoral care; staff in healthcare; and members of junior, middle or top management.

On behalf of our own research group, Hiebel et al. - working in the fields of psychosomatic medicine and psychotherapy, palliative medicine, cultural studies and philosophy - focused on Resilience in Adult Health Science, offering A Narrative Review Synthesis of Process-Oriented Approaches from 2015-202O.

$5 \mathrm{Wu} /$ Feder/Cohen/Kim/Calderon/Charney/Mathé, Understanding Resilience, p. 1. They are referring to Russo/Murrough/Han/Charney/Nestler, Neurobiology of Resilience; Rutter, Resilience as a Dynamic Concept; and Southwick/Charney, The Science of Resilience.

6 Wu/Feder/Cohen/Kim/Calderon/Charney/Mathé, Understanding Resilience, p. 1.

7 Fletcher/Sarkar, Psychological Resilience; Windle, What is Resilience?

8 Fletcher/Sarkar, Psychological Resilience, pp. 29-33: Table 1 ('Definitions') referring, among others, to the works of Luthar, Cicchetti and Becker, Rutter, and Masten; Table 2 ('Theories') referring, among others, to the works of Bonanno and Mancini.

9 Fletcher/Sarkar, Psychological Resilience, p. 3. They are referring, among others, to the works of Rutter, Werner and Ungar. 
Although they clearly shared the reflections of Fletcher and Sarkar concerning the conceptual and methodological inconsistencies preventing us from understanding the complexity of resilience, ${ }^{10}$ they took a different approach. Their objective was "to highlight how resilience is typically conceptualised in adult health research with a particular emphasis on process-oriented approaches", concentrating on "the most salient conceptual and methodological discrepancies within the process-oriented resilience-discourse, and the challenges arising from them"." Hiebel et al. also distinguished "four major waves" of resilience research, each of them presented with extensive references to the state of the art (of which only a few can be named here): "In the first wave, the aim was merely to identify protective factors that contribute to individual resilience. Resilience was mostly a trait-oriented approach to detect a certain personality type [...]. In the second wave, resilience was embedded in developmental and ecological systems", stressing the systematic, systemic and processual dimension of resilience. ${ }^{12}$ "From inception of the ongoing interactions, the third wave tried to create interventions and training to foster resilience when it was not likely to occur naturally. Lately, resilience research has focused in the fourth wave on multilevel dynamics linking genes, neurobiological aspects of development and adaption, behaviour, context and their specific interplays [...]. At the same time, interdisciplinary perspectives on resilience are coming together $[\ldots]^{\prime \prime} .13$

\subsection{Problems with Personality Traits, Bouncing Back and Trainings}

In our research group, we were fortunate to learn from the various interdisciplinary approaches to resilience proposed thus far, including their manifold definitions, respective focus of operationalisation and main critical concerns. As for ourselves, coming from widely different disciplines, such as psychology, palliative care, spiritual and pastoral care on the one hand, and theology and philosophy on the other, we soon realised how different the phenomenon of resilience can be perceived, conceptualised, investigated, operationalised and applied in regard to the specific disciplinary settings, respective target groups, and pragmatic demands of our research. The most problematic approaches

\footnotetext{
10 Hiebel/Rabe/Maus/Peusquens/Radbruch/Geiser, Resilience in Adult Health Science Revisited, p. 14.

11 Hiebel/Rabe/Maus/Peusquens/Radbruch/Geiser, Resilience in Adult Health Science Revisited, p. 2.

12 Hiebel/Rabe/Maus/Peusquens/Radbruch/Geiser, Resilience in Adult Health Science Revisited, p. 2.

13 Hiebel/Rabe/Maus/Peusquens/Radbruch/Geiser, Resilience in Adult Health Science Revisited, p. 2.
} 
included the following. First, even though there is the wide consensus that constructs of personality traits are not particularly helpful, ${ }^{14}$ they are more often the basis of many resilience scales currently in use, ${ }^{15}$ and they are unfortunately highly influential in popular literature on resilience. ${ }^{16}$ Especially in non-scientific literature, they are usually termed as 'qualities' or as 'resilience factors', including, for example, adequate awareness of oneself and others, selfcontrol and self-regulation, positive expectation of self-efficacy, autonomy and social competence, ability of self-expression, ability to meet challenges in an active way, ability to solve problems and sense of coherence or trust. Termed as 'personality traits', they are often considered as general, non-temporal and non-situated traits that are expected to work as a 'protective shield' against any adversity.

Second, the well-known idea of resilience as 'bouncing back', originally developed in material sciences, is quite often in play here. However, it certainly does not cover the complex issue of resilience. ${ }^{17}$ Resilience is then (more often than not) conceptualised and visualised as a type of protective automatism. Even though there might be some type of natural genetic pre-disposition to the resilience involved, the problem here is that resilience is more likely to be received as an either-or concept, i.e. either you are a resilient individual who is prepared for all types of adversity, or you are not. Both expectations are problematic as those who consider themselves as resilient might find themselves unprepared when experiencing adversity. Meanwhile, those who consider themselves as non-resilient might view it as a natural disadvantage, bad luck or a disappointing/discouraging outcome.

Third, given such expectations, it is no surprise that resilience trainings have become quite popular in larger companies and in business administration. Specifically, they are usually driven by the intention to help their staff perform successfully, enhance their health and well-being, raise their team spirit, find a better work-life balance and strengthen their hardiness against everyday challenges. The companies themselves are seldom to blame for they are more likely to act in good faith, since the idea of strengthening resilience is quite

14 Cf. Southwick/Bonanno/Masten/Panter-Brick/Yehuda, Resilience Definitions, Theory, and Challenges; Hiebel/Rabe/Maus/Geiser, Gibt es die „resiliente Persönlichkeit“?

15 Cf. Wagnild/Young, Development and Psychometric Evaluation of the Resilience Scale; Hiebel/Rabe/Maus/Peusquens/Radbruch/Geiser, Resilience in Adult Health Science Revisited, p. 2.

16 Cf. Richter/Blank, „Resilienz“ im Kontext von Kirche und Theologie; Richter, Einleitung: Ohnmacht und Angst aushalten; Korsch/Richter (eds.), Die heilende Kraft des Sinns.

17 Hiebel/Rabe/Maus/Peusquens/Radbruch/Geiser, Resilience in Adult Health Science Revisited, p. 10. 
tempting for economic and leadership reasons. In this case, resilience is taken as a capability that individuals are supposed to achieve through instruction and training. ${ }^{18}$ Again, there is nothing wrong with the idea of strengthening resilience and raising awareness of certain factors such as the need for social support, the perceptions of oneself and others, trust and a sense of coherence. Yet, the notion of 'training' might be associated with a type of 'fitness', as if we could train resilience like training for a marathon.

Hence, even though both versions ('bouncing back' and 'training') are easy to understand concerning their motivation, they are problematic in at least two further respects. On the one hand, they turn resilience into a quality or goal of longing and desire. On the other hand, they turn resilience into a powerful instrument of neo-liberal programmes that optimise individuals, enabling them to perform more efficiently, especially in highly competitive environments such as business administration and leadership. This is not only in danger of implying an elitist and exclusive tendency, which is contradictory to the once inclusive tendency of resilience research ${ }^{19}$ and its relevance for clinical diagnostics, therapy and pastoral care, but it is also in danger of strengthening the justification and stabilisation of economic and political systems. In regard to the latter, increasing competition for economic reasons, instead of enhancing individual achievement and sustainable development, can be detrimental, as claimed by Slaby, Wendel, Endreß and Rosa. ${ }^{20}$

In our research group, we found it most interesting that such neo-liberal aspects are probably mirrored (in a subversive manner) in the classic set of resilience factors for two reasons. First, as these factors are usually connected to active notions, all of them include capabilities on a considerably high level. Yet, in therapeutic settings, especially in palliative care and pastoral care, we often meet individuals who experience severe stress/trauma and might be unable to perform in such active ways, but can still react in resilient ways. Second, the classic set of resilience factors is, to a high extent, normatively oriented towards powerful and high-performing capacities. For what would be the adequate perception of oneself and others or the ability to control

18 Among the scientifically well-grounded approaches are: Bengel/Meinders-Lücking/ Rottmann, Schutzfaktoren bei Kindern und Jugendlichen; Welter-Enderlin/Hildebrand, Resilienz - Gedeihen trotz widriger Umstände; Fröhlich-Gildhoff/Rönnau-Böse, Resilienz; Garbarino, The Positive Psychology of Personal Transformation; Kalisch, Der resiliente Mensch.

19 Werner/Bierman/French, The Children of Kauai.

20 For example, see Slaby, Kritik der Resilienz; Wendel, Resilienz - Diskursive, machtbesetzte und performative Körperpraxis; Endreß/Maurer, Resilienz im Sozialen; Rosa, Eskalation oder Ausweg? 
oneself? What type of individual or character would we have in mind to expect social competence or have the competence to solve problems/conflicts? How would we define the ability to meet and address new challenges? In which way would we picture the ability to adequately express oneself? It is out of question that based on these factors, many impressive individuals come to mind, which we truly honour and respect for their agency and convincing leadership qualities. Still, given the context of our research group, this does not cover the entire issue of resilience. In fact, there are other forms of resilience that are less active, less outspoken and less obvious at first sight. Hence, in our own approach, we include passive and mediopassive modes of apperception and reaction, i.e. modes and forms of coping that we have especially gained from the perspective of religion and spirituality.

\subsection{Resilience as a Phenomenon of Crisis}

As a consequence, we shared the fundamental critique of resilience and made it one of our starting points of research, regardless of the fact that we consider resilience as a concept of major importance. ${ }^{21}$ In addition to the aforementioned points, the problem of picturing resilience as an innocent, positive quality (given before and in contrast to adversity) as well as a type of training is that it is likely to develop and manifest when actually facing adversity. Thus, it is only in and through the experience of severe crises (e.g. severe illness or the loss of a loved one) that we will know whether we are able to cope in a resilient manner. Moreover, the moment we realise that we might indeed experience a resilient process is the bitter moment when we actually realise the high cost of such recognition. In this regard, resilience is so closely tied to experiences of stress and/or adversity that we might as well refer to it as a complex, ambivalent "phenomenon of crisis par excellence". ${ }^{22}$

We know from trauma research that psychophysical structures and their mental, cognitive and emotional phenomena depend on biochemical, (epi-)genetic factors as well as psychological, behavioural, social, cultural and spiritual factors. Furthermore, traumatic experiences or chronic stress not only inflict acute mental wounds, but they also permanently inscribe themselves via neural codes and networks. ${ }^{23}$ Such processes do not occur in a type

21 Richter/Blank, "Resilienz" im Kontext von Kirche und Theologie; Richter, Einleitung: Ohnmacht und Angst aushalten; Richter/Geiser, „Hilft der Glaube oder hilft er nicht?“

22 Richter, Das Selbst als Balanceakt von Physis und Psyche in Leiblichkeit, Ratio und Affektivität, p. 164 .

23 Cf. Zerach/Solomon/Cohen/Ein-Dor, PTSD, Resilience and Posttraumatic Growth Among Ex-Prisoners of War and Combat Veterans; Jin/Xu/Liu/Liu, Posttraumatic Stress Disorder and Posttraumatic Growth Among Adult Survivors of Wenchuan Earthquake After 1 Year. 
of abstract sphere or in a vacuum, but they are embedded in the biographies, social and cultural values and attitudes belonging to an individual's identity. Therefore, even the empirical approaches of the life sciences demonstrate the close interaction between natural, psychological and socio-cultural processes, calling for interdisciplinary cooperation with the humanities.

\section{3 \\ Resilience as a Multi-Dimensional and Dynamic Process of Adaption}

In our research group, we proposed resilience as a multi-dimensional, nonnormative dynamic process of adapting to stress and adversity by maintaining functionality and mental health, while including fluctuations across time and situations. ${ }^{24}$ However, even though we were able to propose a clear approach to the notion of resilience, we found it increasingly difficult to work with precise definitions of resilience on the one hand, while describing and understanding the phenomenon of resilience in its full complexity on the other. Most importantly, even though the outcome of a resilience process must be well-defined within the health sciences, this does not mean that it should be normatively set in a general manner. Instead, the definition of such outcome should (at least) take into account the respective type of adversity, the relation to factors and mechanisms as well as the research context, target group and methodological approach. ${ }^{25}$

Part of the complex phenomenon of resilience and its process are baseline characteristics, as preconditions of the psychophysical constitution of individuals that provide a sound basis for meeting difficult challenges. ${ }^{26}$ Even in their non-normative evaluation, they are relevant as protective or risk factors in relation to mental distress when facing adversity and in all fields of diagnostic treatment and therapy when attempting to identify high-risk groups and protective factors suitable for primary prophylaxis. Such factors are also relevant

24 Cf. Hiebel/Rabe/Maus/Peusquens/Radbruch/Geiser, Resilience in Adult Health Science Revisited. They are referring to Luthar/Cicchetti/Becker, The Construct of Resilience; Rutter, Resilience as a Dynamic Concept; Stainton/Chisholm/Kaiser/Rosen/Upthegrove/ Ruhrmann/Wood, Resilience as a Multimodal Dynamic Process; Masten/Cicchetti, Resilience in Development; Masten/Motti-Stefanidi, Multisystem Resilience for Children and Youth in Disaster.

25 Cf. Hiebel/Rabe/Maus/Peusquens/Radbruch/Geiser, Resilience in Adult Health Science Revisited.

26 For example, see Windle/Bennett/Noyes, A methodological review of resilience measurement scales; Herrmann/Stewart/Diaz-Granados/Berger/Jackson/Yuen, What is Resilience?; Wagnild/Young, Development and Psychometric Evaluation of the Resilience Scale. 
to demographic aspects such as age, sex/gender, family status and chosen way of life, economic situation and education, social context and interaction, cultural and religious/spiritual traditions and rituals, inter- and intra-personal values and habits and individual preferences and goals. As such baseline characteristics, the factors as well as the resources they provide will develop over time, will never remain stable or static and be bound to their situated and flexible contexts.

Another fundamental part of the resilience process is the relation and difficult distinction between factors and mechanisms. On the one hand, it is safe to say that factors describe the precondition of an individual, while mechanisms describe how he/she copes with adversity. In many psychological approaches, the term mechanisms imply aspects of regularity, causality and functionality, even though they do not imply a simplifying automatic mode in a purely technical sense. In this way, factors facilitate mechanisms and both contribute to an individual's outcome. To put it another way, mechanisms are the link between factors and outcomes. Conversely, it is obvious that factors, such as adequate self-control or the ability to ask for help, turn into mechanisms when facing adversity or asking for help during crises. Hence, the idea of a causal relation cannot suffice.

This is even more so if we consider the third part of the resilience process, namely, outcomes. Within the medical disciplines, the outcome of a therapeutic treatment or intervention is of utter interest and must be pre-defined to make evaluations possible, apart from the fact that pre-defined outcomes make the therapeutic process more transparent, trustworthy and reliable for patients/ clients. This is easy to understand for all types of direct causal medical aid such as stabilising a broken bone in bandages/plaster so that it will heal properly and regain as much functionality as possible. If we take oncological chemotherapy as another example, the necessity of a defined outcome becomes even more important, since its causal effect of preventing cancer cells from reproducing also causes damage to cells, chronic fatigue, hair loss, soreness, sickness, etc. The interesting issue here is that the outcome must be carefully evaluated in relation to the healing and damaging effects, and the balance between prolonged life expectancy and quality of life. This opens the door for all types of mental, social, emotional and spiritual coping mechanisms. It might even be that one of the preferred outcomes in experiences related to oncological or other autoimmune diseases is resilience itself. Yet, according to Hiebel et al., the problem of defining a possible outcome for resilience becomes even more obvious: Resilience is often defined by specific outcomes such as the presence or absence of good mental and/or physical health or illness (referring to 
Kalisch et al. ${ }^{27}$ ) or "surrogate outcomes such as functionality (e.g. employment, marriage, good interpersonal relations) or stress perception (Cosco et al., 2017; Chmitorz et al., 2018)". ${ }^{28}$ In this regard, they stated: "As far as we know, there is no universally established outcome measure for resilience itself". 29

From the perspective of our research group, when combining the humanities and the life sciences, the distinction between factors, mechanisms and outcomes seems to be more a matter of hermeneutics, instead of clear-cut definitions (even though we cannot do without the definitions). If we take mindfulness as an example, it may serve all three aspects: 1 ) as a factor of resilience (e.g. practicing mindfulness may reduce an individual's stress when facing adversity); as a mechanism (e.g. practicing mindfulness may enhance an individual's coping skills); and/or as an outcome (e.g. practicing coping skills may improve an individual's mindfulness, calmness and composure). Another example can be seen in social contexts such as a flourishing neighbourhood or being part of a religious community. This will also have a formative and perhaps strengthening influence on an individual's identity before experiencing adversity. At the same time, it will help him/her find new forms of social interaction or spiritual consolation, which may become embedded mechanisms in the coping process. In any case, the interaction between factors, mechanisms and outcomes surely support the idea that resilience is a multi-dimensional and dynamic process of adaption. Powerlessness and the Mediopassive

Given the mutual interaction between the factors, mechanisms and outcomes of resilience, we consider (as equally important) an individual's tolerance towards ambiguity and complexity, and his/her ability to meaningfully articulate and transform negative experiences into positive emotions, perceptions, appraisals and expectations. Again, these issues come almost naturally with coping processes during times of adversity. Otherwise, the notion of adversity would lose its core point. Nevertheless, the aforementioned critique of

27 Kalisch/Müller/Tüscher, A Conceptual Framework for the Neurobiological Study of Resilience.

28 Cf. Cosco/Kaushal/Hardy/Richards/Kuh/Stafford, Operationalising Resilience in Longitudinal Studies; Chmitorz/Kunzler/Helmreich/Tüscher/Kalisch/Kubiak/Wessa/Lieb, Intervention Studies to Foster Resilience.

29 Hiebel/Rabe/Maus/Peusquens/Radbruch/Geiser, Resilience in Adult Health Science Revisited, p. 3 . 
resilience shows that it is not completely self-evident that the positive concept of resilience should be that close to experiences of ambivalence and negativity, which we consider relevant for experiences of endurance and the formation of powerlessness, fear and anxiety. Accordingly, how did we get this notion?

In regard to this question, it was because our project started from within theology, i.e. the academic reflection of the Jewish-Christian tradition established in European German-speaking countries. Even though the theological departments for historic and pragmatic reasons collaborate as confessional departments (i.e. Protestant theology, Roman-Catholic theology, Orthodox theology and Old Catholic theology), theology is not a religious or spiritual practice or religious speech itself, but a critical reflection using standardised methods based on cultural theory, history, philology, critical exegesis, philosophy of religion, ethics, sociology and psychology of religion, systemic theories, etc.

From this perspective, we realised a problem in ongoing resilience research, that religion and spirituality are well recognised as factors in many resilience scales, but they are seldom specified. Moreover, the question of whether religion and spirituality can enhance resilience or whether they actually help in times of adversity is much more complex than a simple yes or no answer. What is true for all types of resilience factors, mechanisms and outcomes is especially true for religion and spirituality: As there is no such thing as religion or spirituality per se, their analysis calls for the insight that neither factors, neither mechanisms nor outcomes come as abstract, general concepts. Instead, they are concrete, embodied, contextual and situated variations bearing all ambiguities of an individual's life. A specific tradition and practice, for example the Christian Eucharist or the shared community in common prayer, may well have been the source of one's identity and prove as an important resource once he/she faces adversity, but as we unfortunately know (and critical theology stresses), it can also be what caused the adversity in the beginning. Hence, resilience factors, mechanisms and outcomes in religion and spirituality must be investigated based on analyses, specific traditional religious texts, reflections, beliefs, spiritual practices, habits etc., as demonstrated in Katharina Opalka's paper On Healing. ${ }^{30}$

In the theological sub-projects in our group, we analysed the following: the materials of the Jewish-Christian tradition, originating from the context of the Ancient Near East (e.g. Psalms and Lamentations); the Hellenistic and Roman traditions in early Christianity (e.g. the theologies of the Passion of Christ and the Resurrection); their reception in younger spiritual movements, e.g. in the

30 Cf. Opalka, On Healing; Richter (ed.), Ohnmacht und Angst aushalten; Korsch/ Richter (eds.), Die heilende Kraft des Sinns; Richter/Alles, „... und ganz gewiss an jedem neuen Tag“. 
Communauté de Taizé or in secularised spiritual practices such as mindfulness and the way traditional elements may (or may not) be present in our target groups.

Even though the Jewish-Christian tradition has grown out of an extremely wide range of cultural traditions covering a time frame of approximately 3,500 years, we nevertheless found an intriguingly interesting and common concentration on the questions of ambiguity and ambivalence, especially in the relation and interaction between darkness and light, suffering and redemption, anxiety and comfort and despair and hope. The Christian creed, in its very core, focuses on the idea of integrating negativity in the process of deliverance, redemption and fulfilment. In other words, it is in and through death or powerlessness that we see life anew and become empowered. Moreover, the negativity of death and the powerlessness of the tortured and crucified body is neither denied nor stressed per se, but they are integrated into the positive promise that in pain and death, the final decision has not been made, even though it is the actual place for opening the perspective on consolation and fulfilment. In this regard, the cross eventually stands empty, transforming the icon of torture into a symbol of hope beyond death. This religious idea, which has driven theological reflection and liturgical practice since the first centuries, is not only captured in the annual, five-day commemoration and celebration of Maundy Thursday, Good Friday and Easter, but it is also expressed in the manifold Biblical texts, especially the narratives, hymns, prayers, songs, symbols and metaphors Christians use to express their faith. As Katharina Opalka demonstrated in her paper on Paul Tillich's thought-provoking theology, "healing and resilience understood as healing and resilience in spite of can name, admit and value adversity or sickness without elevating them, as in some mystical understandings of suffering". ${ }^{31}$

Given the idea of resilience as a multi-dimensional (not a normatively predefined) dynamic process of adapting to stress and adversity, religious and spiritual traditions not only emphasise the active and passive, but also mediopassive apperceptions and formative processes. This can easily be shown for personal resources such as hope, optimism, sense of coherence, habitual styles of coping or a strong psychic structure, e.g. in bonding. ${ }^{32}$ Interestingly, none of them is the result of an individual's active engagement nor can it be reduced

31 Katharina Opalka, On Healing, xxx. Here she is referring to Tillich, CtB, p. 214 et seq.

32 Cf. Keller/Klein/Hood, Deconversion and Religious or Spiritual Transformation; Geiser, Ärztliches Handeln in der Psychoonkologie: zur Vermittlung von Hoffnung; Marriner/ Cacioli/Moore, The Relationship of Attachment to Resilience and Their Impact on Perceived Stress; Neyer/Asendorpf, Psychologie der Persönlichkeit. 
to his/her passive reaction. Instead, they are based on the mutual interaction between biographical experience, cultural setting, the language in which they are expressed and the situated context in which they are formed. In all of these aspects, individuals find themselves in a place where they can express themselves anew in the words of their given language(s). Even though it is the individual that seeks meaningful expression (be it in philosophical, religious or spiritual meaning), it refers to pre-given beliefs and symbols and traditions and practices so that active and passive modes interfere. ${ }^{33}$

As for the concept of the mediopassive, we refer to Béatrice Han-Pile, who in 2009 introduced it as a theoretical concept. ${ }^{34}$ The mediopassive was also understood to be explicated for/in actions (mainly verbs) and as a diathesis to the active and passive. Additionally, mediopassive actions were considered to be pre-reflexive and non-volitional (at least in their intention), which refers to the passive component of such actions. This component was (at least related to) the starting point of the action being beyond control. In 2017, Han-Pile started a second approach, which concentrated more on the notion of powerlessness as a programmatic term: ${ }^{35}$ Other than in 2009, the subject in mediopassive actions in 2017 understood herself as mediopassive. In this case, the mediopassive was explicated for the subject's own actions (mainly verbs), and it integrated the actions' passive component into the active component. Yet, the passive component of the mediopassive actions seemed to be experienced in a pre-reflexive manner, since the action was not driven by volition. Moreover, the passive component was (at least) related to the starting point of the action and the intended objective, which was considered to be beyond control.

Beyond her previous work, in 2020, Han-Pile offered the following characterisation of mediopassivity: ${ }^{36} \mathrm{~A}$ mediopassive exercise of agency is given

33 This is a core point that is even captured in the international consensus definition of palliative medicine: "Spirituality is a dynamic and intrinsic aspect of humanity through which persons seek ultimate meaning, purpose, and transcendence, and experience relationship to self, family, others, community, society, nature, and the significant or sacred. Spirituality is expressed through beliefs, values, traditions and practices". Puchalski/ Vitillo/Hull/Reller, Improving the Spiritual Dimension of Whole Person Care, p. 646.

34 Han-Pile, Freedom and the "Choice to Choose Oneself" in Being and Time; Han-Pile, Nietzsche and Amor-Fati.

35 Han-Pile, Hope, Powerlessness, and Agency.

36 The passages and citations in this paragraph were presented in a lecture by Béatrice Han-Pile at the DFG-FOR 2686 Workshop Mediopassivity, on 01.07.2021 in Bonn. This was based on the new papers: Han-Pile, 'The Doing is Everything': A Middle-voiced Reading of Agency in Nietzsche; and Han-Pile, Medio-Passive Agency. Any responsibilities with misunderstandings are to be left with Cornelia Richter. 
"when agents understand themselves as engaged with an internal process they do not control and respond without seeking control over this process". In the following, she further clarified this characterisation by explaining the terms understanding, responsiveness and control and process. First, understanding was introduced by Han-Pile as an individual's background, governing his/her comportment in response to a situation. It is not considered to be fully expressible or thinkable, since it is pre-reflective to a high extent and it includes too many ramifications and changes. In addition, understanding oneself as engaged is not supposed to include forms of self-control, but a processable sense of self, i.e. a self in the process of self-understanding during an exercise of agency. Second, regarding responsiveness and control, Han-Pile discussed them in relation to the experience of powerlessness. Hence, they are not a question of the active or passive, but they refer to an "exercise of agency [...], constrained by a degree of powerlessness within a specific situation 'that the agent is pre-reflectively aware of"'. Third, according to Han-Pile, mediopassive exercises (e.g. hope, love, acceptance, surrender or contemplativeness) unfold over time. Specifically, these processes are not initiated by the agent according to prior intentions. Instead, the agent finds him/herself in this process and responds to it, which, in turn, further modifies the process.

Han-Pile's concept of the mediopassive and its relation to the notion of powerlessness has been extremely helpful for our own approach, especially as we understand resilience as being closely connected to manifold variations and degrees of endurance and the formation of powerlessness, fear and anxiety. Within this framework, we use the concept of the mediopassive as a theoretical, hermeneutic category for understanding the aforementioned aspects of resilience as a dynamic, multifaceted or multi-dimensional process of adaption to adversity. In this regard, we discuss the following six points. First, the concept of the mediopassive serves as a theoretical category that helps us understand phenomena, experiences, sensations, feelings, etc., which are neither active nor passive per se. It also raises the sensitivity regarding the mutual exchange or interplay between active and passive components. Second, the mediopassive is nothing we 'have' and it is not a substantial quality or a definite momentum. However, it refers to dynamic, processual, changing and fluid movements. Third, the mediopassive comes with moments or aspects of ambiguity. Fourth, the mediopassive makes itself accessible in an instant and it is related to intuition, perception and recognition. Yet, it is pre-reflexive and ex post hardly ever explicable. Fifth, phenomena related to the mediopassive are bound to our embodied, mental and emotional situatedness. In other words, the mediopassive is embedded in and expressed by symmetric and asymmetric interactions, including interactions of (overwhelming) power. 
Finally, phenomena related to the mediopassive are likely to imply aspects of transcendence and therefore, they may be especially open for experiences of religion and spirituality.

In addition to Han-Pile's reflections on the example of powerlessness and hope, her insights can be illustrated by two phenomenological dimensions, which help us understand the concept of the mediopassive. First, there are physical and mental aspects of the mediopassive such as 'letting go' and connecting in sports or music. In this regard, 'letting go' is a dynamic movement of connecting tension and relaxation in physical and mental respects. ${ }^{37}$ It does not happen via the imperatives "let go!" or "hold tight!" but emerges in a process of mutual response. It makes itself felt and realized the very moment the balance is perfect. Such moments may come as a surprise if experienced for the first time, but they may be eventually recognised with experience. Second, there is the religious and/or spiritual notion of transcendence, which is beyond all experience and yet expressible through lived experiences. Meanwhile, spiritual experiences demand physical and mental presence, which further implies ideas and imagination (e.g. the Divine/Holiness; belonging to something greater than us, etc.). However, even though they depend on collective, interand transcultural traditions, rituals, holy spaces (e.g. Biblical texts, the liturgical structure of Sunday services, the Eucharist, or simpley a cathedral, a cross on a mountain summit, etc.), spiritual experiences do not have to be expressed in words and they can never be 'produced' in a predictable way. Specifically, to most individuals, the presence of the Divine will most likely present a dynamic but 'invisible' experience. As a third and perhaps best example of the mediopassive, one might point to prayer. In this regard, praying is an active process in which an individual devotedly asks God to step in and act on his/her behalf when facing adversity. Thus, one might consider the result or outcome as a purely passive one, but as the individual maintains this relationship with God/ the Divine, the mediopassive aspect will not vanish.

Finally, one of the main tasks of our research group is to better understand examples of the mediopassive by focusing on other complex experiences related to resilience, aside from the study of religion and spirituality. In the case, perhaps the most prominent example might be the SARS-CoV-2 crisis.

37 This idea has been developed with Ann-Kathrin Armbruster, who presented a paper on Loslassen - Paradoxale Dynamiken der psycho-physischen Einheit des Menschen at our DFG-FOR 2686 conference Resonanz - Response - Resilienz. Phänomenologische und interdisziplinäre Perspektiven auf existenzielle Erfahrungen von Krise und Vulnerabilität. 


\section{Prospect: Enhancing Our Understanding of Resilience by Investigating the Current SARS-CoV-2 $\mathrm{Crisis}^{38}$}

The SARS-CoV-2 crisis is without a doubt a severe global crisis with high death rates and tragic consequences for social communities, including physical and mental overload for clinical staff, lack of education for children and youth, significant unemployment and long-term economic problems. However, even though the crisis can be thoroughly analysed, it is not a clear-cut crisis, at least not in the European context, especially the German one on which this study is based.

Overall, the SARs-CoV-2 crisis is different from catastrophic events, such as forest fires or floods in which the imperatives during and in the aftermath are clearly listed. In this regard, such imperatives include: saving lives, offering water, food and shelter; offering tools and supplies; and helping the clean-up and rebuilding process. Although all of these aspects are based on social interaction, the SARS-CoV-2 crisis is primarily characterised by a loss of functional social resources and interaction. Specifically, the majority of the public were safe in the sense of accommodations, food and water, electricity and electronic/digital communication and healthcare. Yet, the SARS-CoV-2 crisis shows that as long as resilience is related to active agency, control, self-efficacy or responsibility of the self, it does not sufficiently take into account the complexity of the dynamic and transformative process in which individuals respond to adversity. Meanwhile, the unexpected, rapid and potentially life-threatening development of the pandemic has partially replaced control with a loss of control, self-efficacy with passivity and autonomy of the self with obeying political demands for self-restrictions. Hence, 'resilience' in the SARs-CoV-2 crisis does not consist of active, outward actions, but coherent, calm maintenance of the inner self, despite the restrictions. Moreover, facing limitations, isolation, powerlessness and ambivalence in a resilient way requires both endurance and creativity in order to accept the situation and gain a new (hopeful) perspective.

Another equally interesting feature of the SARS-CoV-2 pandemic is that cultural-symbolic expressions have played a major role in the development of the semantics of this crisis. On the one hand, fear and dread seemed to paralyse society, especially in the first months of the pandemic in 2019/202O.

38 This chapter is based on the research project The Role of Transcultural Semantics and Symbols for Resilience During the Coronavirus Pandemic - A Hermeneutic Approach to Historical and Intercultural Expressions of Severe Crisis by Cornelia Richter, Judith Gärtner, Thiemo Breyer and Matthew R. Robinson, funded by vw-Stiftung 2021-2O22. 
Meanwhile, the hourly news reports included: powerful images of abandoned streets and locations; digital surveillance and police control in China; convoys of the Red Cross delivering patients with SARS-CoV-2 to overcrowded hospitals; and nocturnal military convoys in Italy collecting dead bodies. Such scenes immediately raised expectations to catastrophic and even apocalyptic proportions similar to the Black Death and Biblical plagues. One might ask whether European countries, such as Austria and Germany, would have reacted politically and socially in a different way without the significant impact of the symbolic semantics of what SARs-CoV-2 was supposed to be like. On the other hand, social and political restrictions have led to active resistance, e.g. armed civil demonstrations in the United States, where, even though the media displayed similar pictures, the crisis was thought to only hit weak, cowardly and/ or non-believing individuals or groups. In sum, dramatic expressions and images clearly but unpredictably influenced social and political responses, individual and social meaning-making and corresponding modes of resilience.

Overall, this situation presents both a need and a unique opportunity to expand resilience research towards inter- and transcultural hermeneutics focused on religion, spirituality and existential and empathic concerns for resilience in global crisis management. However, what we will need is a set of hermeneutical criteria for initiating a sound investigation of the symbolic dimension, including both its semantics and transcultural flow. As indicated earlier, it seems at first glance that cultural dynamics have significantly influenced the responses to the SARS-CoV-2 crisis and conditioned the possibilities for resilience. Yet, upon closer examination, it is exceedingly difficult to isolate unique and distinguishing cultural actions or symbols, which, in turn, creates challenges for comparing and contrasting the responses inter- and transculturally. Nevertheless, the goal is to be able to interpret the inter- and transcultural syntax of individual existential crisis management and resilient response. Otherwise, the complexity of resilience will not be sufficiently understood in the global perspective.

\section{Biography}

Dr. Cornelia Richter is professor for Systematic Theology at the University of Bonn since 2012 and co-director of the Bonn Institute for Hermeneutics. She studied Protestant theology and philosophy in Vienna and Munich and achieved her PhD in Systematic Theology at the Philipps-University of Marburg in 2012 ("Die Religion in der Sprache der Kultur. Schleiermacher und Cassirer Kulturphilosophische Symmetrien und Divergenzen", Tübingen 2004). From 
2003-2005, she was Assistant Research Professor at the Center for Subjectivity Research at the University of Copenhagen. In 2010, she did her habilitation in Systematic Theology at the Philipps-University of Marburg ("Bodenloses Vertrauen. Performanzphänomen in Humanwissenschaften und Theologie"). In 2014, Richter started the research project "Resilience in Religion and Spirituality" (DFG-Research Group 2686) at the University of Bonn, an interdisciplinary cooperation of theology, philosophy, psychosomatic medicine and psychotherapy, palliative care and spiritual care. Further research topics: Spirituality and modern liberal theology, ecclesiology, philosophy of religion.

\section{Bibliography}

Bengel, Jürgen/Meinders-Lücking, Frauke/Rottmann, Nina: Schutzfaktoren bei Kindern und Jugendlichen - Stand der Forschung zu psychosozialen Schutzfaktoren für Gesundheit. (Forschung und Praxis der Gesundheitsförderung 35). Köln: BZgA 2009 .

Blum, Sabine/Endreß, Martin/Kaufmann, Stefan/Rampp, Benjamin: Soziologische Perspektiven. In: Rüdiger Wink (ed.): Multidisziplinäre Perspektiven der Resilienzforschung. Leipzig: Springer 2016, pp. 151-177.

Bonanno, George A.: Loss, Trauma, and Human Resilience: Have we Underestimated the Human Capacity to Thrive after Extremely Aversive Events?, in: Am. Psychol. 59 (2004), pp. 20-28.

Bonanno, George A./Galea, Sandro/Bucciarelli, Angela/Vlahov, David: What Predicts Psycholocial Resilience after Disaster? The Role of Demographics, Resources, and Life Stress, in:Journal of Consulting and Clinical Psychology 75 (2007), pp. 671-682.

Bonanno, George A./Romero, Sara A./Klein, Sara I.: The Temporal Elements of Psychological Resilience. An Integrative Framework for the Study of Individuals, Families, and Communities, in: Psychological Inquiry 26 (2015), pp. 139-169.

Chmitorz Andrea/Kunzler, Angela/Helmreich, Isabella/Tüscher, Oliver/Kalisch, Raffael/Kubiak, Thomas/Wessa, Michèle/Lieb, Klaus: Intervention Studies to Foster Resilience - A Systematic Review and Proposal for a Resilience Framework in Future Intervention Studies, in: Clinical Psychology Review 59 (2018), pp. 78-100.

Cosco, Theodore D./Kaushal, Aradhna/Hardy, Rebecca/Richards, Marcus/Kuh, Diana/ Stafford, Mai: Operationalising Resilience in Longitudinal Studies: A Systematic Review of Methodological Approaches, in: Journal of Epidemiology \& Community Health 71 (2017), pp. 98-104.

Endreß, Martin/Maurer, Andres (eds.): Resilienz im Sozialen. Theoretische und empirische Analysen. Wiesbaden: Springer 2015. 
Fletcher, David/Sarkar, Mustafa: Psychological Resilience: A Review and Critique of Definitions, Concepts and Theory, in: European Psychologist 18 (1/2013), pp. 12-23. Fröhlich-Gildhoff, Klaus/Rönnau-Böse, Maike: Resilienz. München/Basel: Uт в ${ }^{5} 2019$. Garbarino, James.: The Positive Psychology of Personal Transformation. Leveraging Resilience for Life Change. New York, NY: Springer 2011.

Geiser, Franziska: Ärztliches Handeln in der Psychoonkologie: zur Vermittlung von Hoffnung, in: Ärztliche Psychotherapie 10 (3/2015), pp. 156-16o.

Han-Pile, Béatrice: Nietzsche and Amor-Fati, in: European Journal of Philosophy 19 (2/2011), pp. 224-261.

Han-Pile, Béatrice: Freedom and the "Choice to Choose Oneself" in Being and Time, in: Mark A. Wrathall (ed.): The Cambridge Companion to Heidegger's 'Being and Time’. Cambridge: Cambridge University Press 2013, pp. 291-319 (2009 online, 2013 published).

Han-Pile, Béatrice: Hope, Powerlessness, and Agency, in: Midwest Studies in Philosophy XLI (1/2017), pp. 175-201.

Han-Pile, Béatrice: 'The Doing is Everything': A Middle-Voiced Reading of Agency in Nietzsche, in: Inquiry 63 (1/2020), pp. 42-64.

Han-Pile, Béatrice: Medio-Passive Agency (in preparation).

Herrmann, Helen/Stewart, Donna E./Diaz-Granados, Natalia/Berger, Elena L./Jackson, Beth/Yuen, Tracy: What is Resilience?, in: The Canadian Journal of Psychiatry $5^{6}$ (5/2011), pp. 258-265.

Hiebel, Nina/Rabe, Lisa Milena/Maus, Katja/Geiser, Franziska: Gibt es die „resiliente Persönlichkeit“?, in: Spiritual Care 10 (2/2021), pp. 117-127.

Hiebel, Nina/Rabe Lisa Milena/Maus, Katja/Peusquens, Frank/Radbruch, Lukas/ Geiser, Franziska: Resilience in Adult Health Science Revisited - A Narrative Review Synthesis of Process-Oriented Approaches, in: Frontiers in Psychology 12 (2021), pp. 1-17.

Jin, Yuchang/Xu, Jiuping/Liu, Hai/Liu, Dongyue: Posttraumatic Stress Disorder and Posttraumatic Growth among Adult Survivors of Wenchuan Earthquake after 1 Year. Prevalence and correlates, in: Archives of Psychiatric Nursing 28 (1/2014), pp. 67-73.

Kalisch, Raffael: Der resiliente Mensch. Wie wir Krisen erleben und bewältigen. Berlin: Berlin Verlag 2017.

Kalisch, Raffael/Müller, Marianne B./Tüscher, Oliver: A Conceptual Framework for the Neurobiological Study of Resilience, in: The Behavioral and Brain Sciences 38 (2015), p. eg2.

Karidi, Maria/Schneider, Martin/Gutwald, Rebecca (eds.): Resilienz. Interdisziplinäre Perspektiven zu Wandel und Transformation. Wiesbaden: Springer 2018.

Keller, Barbara/Klein, Constantin/Hood, Ralph: Deconversion and Religious or Spiritual Transformation, in: Constructs of meaning and religious transformation (2013), pp. 119-142. 
Korsch, Dietrich/Richter, Cornelia (eds.): Die heilende Kraft des Sinns. Viktor E. Frankl in philosophischer, theologischer und therapeutischer Betrachtung (Religion und Gesundheit 2). Stuttgart: Kohlhammer 2018.

Luthar, Suniya S./Cicchetti, Dante/Becker, Bronwyn: The Construct of Resilience: A Critical Evaluation and Guidelines for Future Work, in: Child Development 71 (2000), pp. 543-562.

Mancini, Anthony D./Bonanno, George A.: Predictors and Parameters of Resilience to Loss: Toward an Individual Differences Model, in: Journal of Personality 77 (2009), pp. $1805^{-18} 3^{2}$.

Marriner, Patricia/Cacioli, Jon-Paul/Moore, Kathleen Anne: The Relationship of Attachment to Resilience and Their Impact on Perceived Stress. In: Krzysztof Kaniasty/ Kathleen Anne Moore/Siobhán Howard/Petra Buchwald (eds.): Stress and Anxiety. Applications to Social and Environmental Threats, Psychological Well-Being, Occupational Challenges, and Developmental Psychology. Berlin: Logos Verlag 2014, pp. 73-81.

Masten, Ann S./Cicchetti, Dante: Resilience in Development: Progress and Transformation, in: Dante Cicchetti (ed.): Developmental Psychopathology. Hoboken, NJ: John Wiley and Sons, Inc. 2016, pp. 1-63.

Masten, Ann S./Motti-Stefanidi, Frosso: Multisystem Resilience for Children and Youth in Disaster: Reflections in the Context of COVID-19, in: Adversity and Resilience Science 1 (2020), 95-106.

Neyer, Franz J./Asendorpf, Jens B.: Psychologie der Persönlichkeit. Berlin: Springer ${ }^{6}{ }_{2018}$.

Opalka, Katharina: “On Healing”: Paul Tillich's contribution to current research on resilience, in:JRAT 7 (2/2021), pp. XXX.

Puchalski, Christina M./Vitillo, Robert/Hull, Sharon K./Reller, Nancy: Improving the Spiritual Dimension of Whole Person Care. Reaching National and International Consensus, in:Journal of Palliative Medicine 17 (6/2014), pp. 642-656.

Richter, Cornelia: Das Selbst als Balanceakt von Physis und Psyche in Leiblichkeit, Ratio und Affektivität, in: Elisabeth Gräb-Schmidt (ed.): Was heißt Natur? Philosophischer Ort und Begründungsfunktion des Naturbegriffs (Veröffentlichungen der Wissenschaftlichen Gesellschaft für Theologie 43). Leipzig: Evangelische Verlagsanstalt 2015, pp. 157-173.

Richter, Cornelia: Einleitung:Ohnmacht und Angstaushalten. Zur Kritik und Ergänzung dominant aktiver Resilienzfaktoren. In: Cornelia Richter (ed.): Ohnmacht und Angst aushalten. Kritik der Resilienz in Theologie und Philosophie (Religion und Gesundheit 1). Stuttgart: Kohlhammer 2017, pp. 9-29.

Richter, Cornelia (ed.): Ohnmacht und Angst aushalten. Kritik der Resilienz in Theologie und Philosophie (Religion und Gesundheit 1). Stuttgart: Kohlhammer 2017. 
Richter, Cornelia/Alles, Thorben:,... und ganz gewiss an jedem neuen Tag“. - Bonhoeffer als „role model“ für Resilienz?, in: Cornelia Richter/Simon Peng-Keller (eds.): Resilienz im Kontext von Spiritual Care. Spiritual Care 10 (2/2021), pp. 156-164.

Richter, Cornelia/Blank, Jennifer: „Resilienz“ im Kontext von Kirche und Theologie. Eine kurze Einführung in den Stand der Forschung, in: Praktische Theologie $5^{1}$ (2016), pp. 69-74.

Richter, Cornelia/Geiser, Franziska: „Hilft der Glaube oder hilft er nicht?“ Von den Herausforderungen, Religion und Spiritualität im interdisziplinären Gespräch über Resilienz zu erforschen, in: Cornelia Richter (ed.): An den Grenzen des Messbaren. Die Kraft von Religion und Spiritualität in Lebenskrisen (Religion und Gesundheit 3). Stuttgart: Kohlhammer 2021, pp. 9-36.

Rosa, Hartmut: Eskalation oder Ausweg? Das Ende der dynamischen Stabilisierung und das Konzept der Resonanz. In: Sven Ellmers/Philip Hogh (eds.): Warum Kritik? Begründungsformen kritischer Theorie. Weilerswist: Velbrück Wissenschaft 2017, pp. 339-363.

Russo, Scott J./Murrough, James W./Han, Ming-Hu/Charney, Dennis S./Nestler, Eric J.: Neurobiology of Resilience, in: Nature Neuroscience 15 (11/2012), pp. 1475-1484.

Rutter, Michael: Resilience as a Dynamic Concept, in: Development and Psychopathology 24 (2/2012), pp. 335-344.

Slaby, Jan: Kritik der Resilienz. In: Philipp Wüschner/Frauke A. Kurbacher (eds.): Was ist Haltung? Begriffsbestimmung, Positionen, Anschlüsse. Würzburg: Königshausen und Neumann 2016, pp. 273-298.

Southwick, Stephen M./Bonanno, George A./Masten, Ann S./Panter-Brick, Catherine/ Yehuda, Rachel: Resilience Definitions, Theory, and Challenges: Interdisciplinary Perspectives, in: European Journal of Psychotraumatology 5 (2014).

Southwick, Steven M./Charney, Dennis S.: The Science of Resilience. Implications for the Prevention and Treatment of Depression, in: Science 338 (6103/2012), pp. 79-82.

Stainton, Alexandra/Chisholm, Katharine/Kaiser, Nathalie/Rosen, Marlene/Upthegrove, Rachel/Ruhrmann, Stephan/Wood, Stephen J.: Resilience as a Multimodal Dynamic Process, in: Early Intervention in Psychiatry 13 (2019), pp. 725-732.

Wagnild, Gail M./Young, Heather M.: Development and Psychometric Evaluation of the Resilience Scale, in:Journal of Nursing Measurement 1 (2/1993), pp. 165-178.

Welter-Enderlin, Rosmarie/Hildebrand, Bruno (eds.): Resilienz - Gedeihen trotz widriger Umstände. Heidelberg: Carl-Auer 2012.

Wendel, Saskia: Resilienz - Diskursive, machtbesetzte und performative Körperpraxis. In: Cornelia Richter (ed.): Ohnmacht und Angst aushalten. Kritik der Resilienz in Theologie und Philosophie (Religion und Gesundheit 1). Stuttgart: Kohlhammer 2017, pp. 133-145. 
Werner, Emmy E./Bierman, Jessie M./French, Fern E.: The Children of Kauai. A Longitudinal Study from the Prenatal Period to Age Ten. Honolulu, HI: University of Hawaii Press 1971.

Windle, Gill: What is Resilience? A Review and Concept Analysis, in: Reviews in Clinical Gerontology 21 (2/2011), pp. 152-169.

Windle, Gill/Bennett, Kate M./Noyes, Jane: A Methodological Review of Resilience Measurement Scales, in: Health and Quality of Life Outcomes 9 (8/2011).

Wu, Gang/Feder, Ariane/Cohen, Hagit/Kim, Johanna J./Calderon, Solara/Charney, Denis S./Mathé, Aleksander A.: Understanding Resilience, in: Frontiers in Behavioral Neuroscience 7 (2013), pp. 1-15.

Zerach, Gadi/Solomon, Zahava/Cohen, Assaf/Ein-Dor, Tsachi: PTSD, Resilience and Posttraumatic Growth Among Ex-Prisoners of War and Combat Veterans, in: Israel Journal of Psychiatry and Related Sciences 50 (2/2013), pp. 91-98. 